\title{
Milk as a Food Source of Iodine for Human Consumption in the Czech Republic
}

\author{
J. KURSA, I. HERZIG ${ }^{1}$, J. TRÁVNÍČEK, V. KROUPOVÁ \\ University of Southern Bohemia in České Budějovice, Faculty of Agriculture \\ ${ }^{1}$ Veterinary Research Institute, Brno
}

Received June 3, 2004

Accepted March 3, 2005

\begin{abstract}
Kursa J., I. Herzig, J. Trávníček, V. Kroupová: Milk as a Food Source of Iodine for Human Consumption in the Czech Republic. Acta Vet. Brno 2005, 74: 255-264.

The present study brings current information on providing dairy cows with the required iodine level after determination of its content in milk and on the relationship between its milk concentrations and iodine intake by human population.

Iodine concentration in fresh cow milk from 226 farms covering 66 districts of the Czech Republic was assessed by the Sandell-Kolthoff Method.

Average iodine concentration in a group of 226 bulk samples from distinct localities of the Czech Republic was $310.4 \pm 347.0 \mu \mathrm{g} \mathrm{I} \cdot 1^{-1}$ and significant variations of iodine content in milk from different farms expressed by variation range $<10$ to $>1000 \mu \mathrm{g} \mathrm{I} \cdot 1^{-1}$ was detected. The variations reflected marked differences in iodine saturation of dairy cows. Average milk iodine concentration is twice and a half the findings detected before supplementation which was initiated between the years 1997 - 1999 and is higher than the current European standard.

Deep iodine deficiency in fodder, non-corrected by feed supplements, was found in $4.0 \%$ of milk samples with the values $<20 \mu \mathrm{g} \mathrm{I} \cdot 1^{-1}$. Iodine milk concentrations above $500 \mu \mathrm{g} \mathrm{I} \cdot \mathrm{l}^{-1}$ were detected in $16.8 \%$ farms. After determination of iodine concentrations in the diets fed to dairy cows it is recommendable to regulate the offer of supplements containing iodine according to the physiological requirements of the animals, their production and environmental conditions. General monitoring of iodine concentrations in fresh milk followed by immediate providing the farmers with the results is essential.

It is necessary to consider significantly higher average iodine concentrations in milk purchased by milk processing plants from the farms in the year $2003\left(323.7 \pm 364.3 \mu \mathrm{g} \mathrm{I}^{-1} \mathrm{l}^{-1}\right)$ when iodine intakes through the basketfuls of foodstuffs by consumers are evaluated.
\end{abstract}

Dairy cows, iodine deficiency, iodine supplementation, general monitoring, iodine concentrations in milk

Over the two past decades, special attention was concentrated on iodine supplementation of the inhabitants of the Czech Republic. In relation to current health problems in the animal population, the questions of optimization of iodine intake by farm animals have been in focus by the researchers dealing with veterinary medicine and nutrition. Interdisciplinary approach to the problem of animal saturation with iodine has been motivated by the aim to eliminate the losses caused by clinical forms of thyreopathy both in the past and nowadays (Groppel et al. 1986; Bobek 1998); it was documented by the fact that goitre was diagnosed in 5 to $29.8 \%$ calves from exposed localities of the Czech Republic in the years of 1988 to 1997 which were examined with that particular purpose (Č ada 1988; Kurs a et al. 1997).

The initiative of endocrinologists and hygienists to investigate the possibilities how to increase the low iodine content in milk, meat and eggs and thus to extend the function and participation of food of animal origin in the prevention of iodine deficiency in humans was respected by veterinary and agricultural researchers (Kaufmann 1997; Kaufmann et al. $1998 \mathrm{ab}$ ). This group of foodstuffs are especially significant and non-substitutable under the conditions of our republic, with respect to their consumption and feeding behaviour of the consumers (B orkov cová and Řehůřková 2001).

Address for correspondence:

Prof. MVDr. Jaroslav Kursa, DrSc.

Jihočeská univerzita, fakulta zemědělská

Studentská 13

České Budějovice, Czech Republic
Phone:+420 387772611

Fax:+420 387772611

E-mail: randak@zf.jcu.cz

http://www.vfu.cz/acta-vet/actavet.htm 
Milk iodine concentration corresponds to the level of dairy cow exposure to this trace element. Berg et al. (1988) and Maas et al. (1989) expressed correlation between iodine content in the diet and milk by the correlation coefficient $r=0.66$. Iodine concentration in milk of ruminants is, besides ioduria, commonly used as an indicator of iodine saturation of the organism (Hemken 1980; Franke et al. 1983; Azuolas and Caple 1984; Herzig et al. 1999; Trávníček and Kursa 2001). The same data is related to the results of the experiments testing efficiency of iodine supplementation of feed rations (B erg et al. 1988; Anke et al. 1994a; Herzig et al. 1999).

In relation to the evaluation of the ten year period of complex prophylaxis of iodine deficiency in the Czech Republic we were asked by the Interdisciplinary Committee for Solving Iodine Deficit to monitor the situation in the sphere of agriculture. We included the problem in the proposed study which was accepted by the Veterinary Scientific Committee for Food Safety of the Ministry of Agriculture of the Czech Republic.

The aim of the present study was to obtain an overall knowledge of cow milk iodine levels before processing by food industry followed by updating the substantiations for evaluation of optimal intake by the human population. At the same time, it was targeted at potential risks of extremely high levels of supplementation and at specification of usefulness and significance of the following epidemiological studies with a similar purpose.

\section{Materials and Methods}

Iodine levels in bulk samples of fresh cow milk originating from 226 randomly selected farms covering 66 districts of the Czech Republic were assessed. The milk samples were standard samples collected by qualified personnel from central laboratories of three Czech dairies (Bohušovice n. O., České Budějovice, Pardubice) with the aim to assess the quality level of the purchased raw material. After obtaining the samples, the researchers registered them in such a way so that the extramural anonymity of their origin may be observed, and they were kept frozen before analysis in the laboratory of the Veterinary Research Institute in Brno.

Milk iodine concentration was assessed by spectrophotometric method using alkaline incineration based on the Sandell-Kolthoff reaction (B ednář et al. 1964). The principle of the assessment is reduction of $\mathrm{Ce}^{4+}$ to $\mathrm{Ce}^{3+}$ in the presence of $\mathrm{As}^{3+}$ and catalytic effect of iodine. Mineralization is performed in a dry way in alkaline environment at $600{ }^{\circ} \mathrm{C}$. By that method, total iodine is assessed, i.e. both inorganic and protein-bound iodine.

The findings from the year 2003 were compared with those obtained in our previous investigations in the years 1982 - 1999. It is a synthesis and comparison of results and data from single and repeated detections of bovine milk iodine content performed in 101 herds in Southwest Bohemia, and in the regions of Znojmo and Vsetín.

Statistical analysis of the results included calculation of the mean values, standard deviations, coefficient of variation, minimum and maximum values, median (Matoušková et al. 1992).

\section{Results}

Analysis of bulk samples from 226 places represented determination of iodine levels in about 28000 dairy cows; 124 cows are kept per farm in average. Among a total of about 466000 cows kept for market milk production in the Czech Republic in the year 2003, it is $6 \%$, their market milk production was about 161 million litres milk per year. Milk samples from 66 districts (Table 1) cover $78 \%$ of the territory of the country.

Average milk iodine content reached 310.4 \pm 347.0 micrograms of iodine per litre $\left(\mu \mathrm{g} \mathrm{I} \cdot \mathrm{l}^{-1}\right)$ of fresh cow milk. Minimum and maximum values (Table 1) expressed by the variation range of values $<10$ to $>1000 \mu \mathrm{g} \mathrm{I} \cdot \mathrm{l}^{-1}$ characterize marked variations in iodine concentrations between respective farms. As it is well known that milk iodine concentrations and dairy cow exposure iodine levels do highly correlate, the detected variability shows marked differences in iodine saturation of cows in the Czech Republic.

Average values from different districts with rather high numbers of samples examined also differed significantly. For instance, averages of $105.2 \mu \mathrm{g} \mathrm{I} \cdot \mathrm{l}^{-1}$ and $478.2 \mu \mathrm{g} \mathrm{I} \cdot 1^{-1}$ were detected in the district of Pelhrimov, respectively; we cannot fail to notice that those two districts are neighbouring and very close as for geographical location and environment. 
Table1. Iodine content in milk from dairy cows $\left(\mu \mathrm{g} \mathrm{I} \cdot \mathrm{l}^{-1}\right)$ in respective districts of regions

\begin{tabular}{|c|c|c|c|c|c|c|c|c|}
\hline Region & District & Number & $\mathrm{x}$ & SD & $\mathrm{V} \%$ & Min & Max & Median \\
\hline \multirow[t]{7}{*}{ South Bohemia } & Č.Budějovice & 12 & 449.42 & 576.20 & 128.2 & 24.1 & $>1000$ & 249.3 \\
\hline & Č.Krumlov & 4 & 280.70 & 93.28 & 33.2 & 134.1 & 393.1 & 297.8 \\
\hline & J.Hradec & 10 & 421.34 & 705.50 & 167.4 & 19.9 & $>1000$ & 220.4 \\
\hline & Písek & 3 & 241.03 & 37.80 & 15.7 & 197.4 & 289.6 & 236.1 \\
\hline & Prachatice & 5 & 193.70 & 30.70 & 15.8 & 145.6 & 226.4 & 206.5 \\
\hline & Strakonice & 2 & 79.55 & 25.55 & 32.1 & 54.0 & 105.1 & 79.6 \\
\hline & Tábor & 7 & 105.20 & 75.37 & 71.6 & 12.0 & 245.9 & 99.3 \\
\hline \multirow[t]{6}{*}{ South Moravia } & Blansko & 3 & 193.17 & 181.78 & 94.1 & 32.0 & 447.2 & 100.3 \\
\hline & Brno-country & 2 & 378.25 & 167.35 & 44.2 & 210.9 & 545.6 & 378.2 \\
\hline & Břeclav & 3 & 255.47 & 176.54 & 69.1 & 127.4 & 505.1 & 133.9 \\
\hline & Hodonín & 2 & 199.10 & 9.70 & 4.9 & 189.4 & 208.8 & 199.1 \\
\hline & Vyškov & 3 & 357.20 & 317.63 & 88.9 & 36.4 & 789.9 & 245.3 \\
\hline & Znojmo & 3 & 238.87 & 123.70 & 51.8 & 87.5 & 390.5 & 238.6 \\
\hline \multirow[t]{5}{*}{ Hradec Králové } & Hradec Králové & 3 & 261.53 & 183.91 & 70.3 & 55.0 & 501.7 & 227.9 \\
\hline & Jičín & 2 & 169.65 & 86.15 & 50.8 & 83.5 & 255.8 & 169.6 \\
\hline & Náchod & 2 & 45.90 & 39.20 & 85.4 & 6.7 & 85.1 & 45.9 \\
\hline & Rychnov n.K. & 3 & 144.87 & 123.90 & 85.5 & 25.4 & 315.6 & 93.6 \\
\hline & Trutnov & 2 & 560.15 & 205.55 & 36.7 & 354.6 & 765.7 & 560.2 \\
\hline \multirow[t]{4}{*}{ Liberec } & Česká Lípa & 3 & 167.90 & 109.71 & 65.3 & 29.3 & 297.6 & 176.8 \\
\hline & Jablonec n.Nisou & 3 & 177.17 & 119.03 & 67.2 & 22.6 & 312.2 & 196.7 \\
\hline & Liberec & 2 & 101.60 & 53.40 & 52.6 & 48.2 & 155.0 & 101.6 \\
\hline & Semily & 3 & $>1000$ & 439.39 & 43.0 & 406.2 & $>1000$ & $>1000$ \\
\hline \multirow[t]{6}{*}{ Moravia-Silesia } & Bruntál-Jeseník & 3 & 191.67 & 134.49 & 70.2 & 2.1 & 299.9 & 273.0 \\
\hline & Frýdek-Místek & 3 & 105.43 & 37.95 & 36.0 & 78.3 & 159.1 & 78.9 \\
\hline & Karviná & 3 & 531.03 & 100.49 & 18.9 & 428.7 & 667.6 & 496.8 \\
\hline & Nový Jičín & 2 & 181.45 & 159.65 & 88.0 & 21.8 & 341.1 & 181.4 \\
\hline & Opava & 3 & 229.50 & 42.58 & 18.6 & 169.4 & 262.9 & 256.2 \\
\hline & Ostrava & 2 & 148.05 & 35.85 & 24.2 & 112.2 & 183.9 & 148.0 \\
\hline \multirow[t]{4}{*}{ Olomouc } & Olomouc & 2 & 378.85 & 76.45 & 20.2 & 302.4 & 455.3 & 378.8 \\
\hline & Prostějov & 2 & 395.55 & 1.55 & 0.4 & 394.0 & 397.1 & 395.6 \\
\hline & Přerov & 3 & 580.70 & 523.26 & 90.1 & 65.7 & 1298.4 & 378.0 \\
\hline & Šumperk & 3 & 168.73 & 80.82 & 47.9 & 55.5 & 238.8 & 211.9 \\
\hline \multirow[t]{4}{*}{ Pardubice } & Chrudim & 2 & 87.95 & 19.05 & 21.7 & 68.9 & 107.0 & 88.0 \\
\hline & Pardubice & 3 & 209.10 & 38.33 & 18.3 & 163.4 & 257.2 & 206.7 \\
\hline & Svitavy & 3 & 173.83 & 18.07 & 10.4 & 157.9 & 199.1 & 164.5 \\
\hline & Ústí nad Orlicí & 3 & 155.93 & 32.72 & 21.0 & 110.0 & 183.8 & 174.0 \\
\hline \multirow[t]{6}{*}{ Plzeň } & Domažlice & 2 & 388.65 & 338.65 & 87.1 & 50.0 & 727.3 & 388.6 \\
\hline & Klatovy & 2 & 81.00 & 70.40 & 86.9 & 10.6 & 151.4 & 81.0 \\
\hline & Plzeň-south & 3 & 221.20 & 91.17 & 41.2 & 143.1 & 349.1 & 171.4 \\
\hline & Plzeň-north & 3 & 458.30 & 261.71 & 57.1 & 133.9 & 774.8 & 466.2 \\
\hline & Rokycany & 2 & 306.10 & 203.10 & 66.4 & 103.0 & 509.2 & 306.1 \\
\hline & Tachov & 3 & 740.97 & 31.63 & 4.3 & 718.0 & 785.7 & 719.2 \\
\hline
\end{tabular}


Table1 continued. Iodine content in milk from dairy cows $\left(\mu \mathrm{g} \mathrm{I} \cdot \mathrm{l}^{-1}\right)$ in respective districts of regions

\begin{tabular}{|c|c|c|c|c|c|c|c|c|}
\hline Region & District & Number & $\mathrm{x}$ & SD & $\mathrm{V} \%$ & Min & Max & Median \\
\hline \multirow[t]{10}{*}{ Central Bohemia } & Benešov & 11 & 301.48 & 259.41 & 86.0 & 58.6 & 821.2 & 155.6 \\
\hline & Beroun & 2 & 324.80 & 15.10 & 4.6 & 309.7 & 339.9 & 324.8 \\
\hline & Kladno & 5 & 95.26 & 52.83 & 55.5 & 40.8 & 192.2 & 86.6 \\
\hline & Kolín & 3 & 544.47 & 419.41 & 77.0 & 132.5 & $>1000$ & 380.9 \\
\hline & Kutná Hora & 8 & 255.41 & 86.72 & 33.9 & 63.2 & 353.4 & 265.5 \\
\hline & Mladá Boleslav & 3 & 737.63 & 579.65 & 78.6 & 277.0 & $>1000$ & 380.7 \\
\hline & Nymburk & 4 & 404.45 & 145.96 & 36.19 & 248.1 & 587.2 & 391.2 \\
\hline & Praha-east & 4 & 369.10 & 133.53 & 36.2 & 275.0 & 599.6 & 300.9 \\
\hline & Praha-west & 1 & 533.00 & 0.00 & 0.0 & 533.0 & 533.0 & 533.0 \\
\hline & Rakovník & 3 & 282.47 & 300.10 & 106.2 & 47.2 & 706.0 & 94.2 \\
\hline \multirow[t]{5}{*}{ Ústí nad Labem } & Chomutov & 2 & 78.20 & 25.10 & 32.1 & 53.1 & 103.3 & 78.2 \\
\hline & Litoměřice & 5 & 153.60 & 103.85 & 67.6 & 16.5 & 291.6 & 176.8 \\
\hline & Louny & 5 & 210.84 & 115.23 & 54.6 & 46.7 & 344.4 & 177.2 \\
\hline & Most & 2 & 75.40 & 58.80 & 78.0 & 16.6 & 134.2 & 75.4 \\
\hline & Ústí nad Labem & 1 & 6.60 & 0.00 & 0.0 & 6.6 & 6.6 & 6.6 \\
\hline \multirow[t]{5}{*}{ Vysočina } & Havlíčkův Brod & 3 & 100.13 & 71.20 & 71.1 & 39.1 & 200.0 & 61.3 \\
\hline & Jihlava & 2 & 813.45 & 359.35 & 44.2 & 454.1 & $>1000$ & 813.4 \\
\hline & Pelhřimov & 11 & 478.26 & 237.31 & 49.6 & 44.4 & 918.1 & 514.1 \\
\hline & Třebíč & 3 & $>1000$ & 752.64 & 69.4 & 51.0 & $>1000$ & $>1000$ \\
\hline & Ždár n. Sázavou & 2 & 488.00 & 154.20 & 31.6 & 333.8 & 642.2 & 488.0 \\
\hline \multirow[t]{4}{*}{ Zlín } & Kroměříž & 3 & 68.80 & 20.47 & 29.8 & 47.9 & 96.6 & 61.9 \\
\hline & Uh. Hradišstě & 3 & 115.30 & 88.43 & 76.7 & 3.3 & 219.5 & 123.1 \\
\hline & Vsetín & 3 & 212.47 & 31.68 & 14.9 & 179.0 & 255.0 & 203.4 \\
\hline & Zlín & 3 & 226.33 & 42.57 & 18.8 & 180.6 & 283.1 & 215.3 \\
\hline
\end{tabular}

A high variability of values is much more marked when each district is evaluated separately; the differences between minimum and maximum values are also apparent. Considering districts with rather a high frequency of sampling sites ( $\mathrm{n}=7$ to 14$)$, they are as follows: Benešov (58.6 to $\left.821.2 \mu \mathrm{g} \mathrm{I} \cdot \mathrm{l}^{-1}\right)$, České Budějovice $\left(24.1\right.$ to $\left.1988 \mu \mathrm{g} \mathrm{I} \cdot \mathrm{l}^{-1}\right)$, Jindřichův Hradec (19.9 to $\left.2512 \mu \mathrm{g} \mathrm{I} \cdot 1^{-1}\right)$, Třebíč (51,0 to $1820 \mu \mathrm{g} \mathrm{I} \cdot \mathrm{l}^{-1}$ ) and Pelhřimov (44.4 to $918.1 \mu \mathrm{g}$ $\left.\mathrm{I} \cdot \mathrm{l}^{-1}\right)$. Findings from closely neighbouring localities reflect similar conditions, for instance two samples from the same district were as follows: Jablonec n. Nisou 22.6 to 312.2, Klatovy 10.6 to 151.4, Nový Jičín 21.8 to 341.1 and Rychnov n. Kněžnou 25.4 to $315.6 \mu \mathrm{g} \mathrm{I} \cdot \mathrm{l}^{-1}$.

Table 2 and Fig. 1 show that the lowest average milk iodine contents $38.7 \pm 49.8$ or 31.4 $\pm 16.4 \mu \mathrm{g} \mathrm{I} \cdot \mathrm{l}^{-1}$ were detected in southwest Bohemia in the years between 1988 to 1996 and in the region of Vsetín in the years between 1992 and 1994, i. e. $28.4 \pm 10.9 \mu \mathrm{g} \mathrm{I} \cdot \mathrm{l}^{-1}$. The situation was associated with low iodine content in fodder and non-sufficient supplementation, and was accompanied by goitre diagnosed in calves. Average milk iodine content increased to $128.7 \pm 53.0 \mu \mathrm{g} \mathrm{I} \cdot \mathrm{l}^{-1}$ detected in the years between 1997 and 1999, reflected higher offer of mineral feed supplements of different provenience and their feeding to dairy cows.

Results from the year 2003 characterize the past four years as a period of substantial increase in milk iodine content. The recorded average value of $310.4 \mu \mathrm{g} \mathrm{I} \cdot \mathrm{l}^{-1}$ is 8.5 -fold the critical value from the year 1988; after having given the supplementation again during the years 1997 to 1999 , it was 2.5-fold higher. 


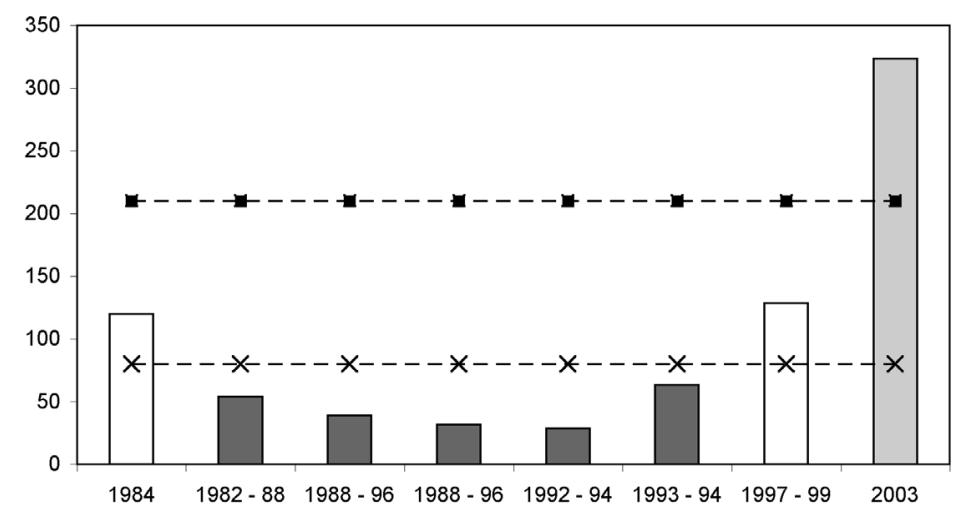

Fig 1. Iodine concentration in milk ( $\mu \mathrm{g} \mathrm{I} \cdot 1^{-1}$ ) of dairy cows in the Czech Republic in years 1984-2003: Šucman et al. (1984), Kroupová and Brožová (1986), Kroupová et al. (1981), Herzig et al. (1996), Herzig et al. (1999), Kroupová et al. (2001), Kursa and Herzig (2003)

Table 2. Dynamics of dairy cow milk iodine concentration in the Czech Republic in years 1982-2004 (Kroupová et al. 2001; Kursa and Herzig 2003)

\begin{tabular}{|c|c|c|c|c|c|c|}
\hline \multirow{3}{*}{ Region } & \multirow{3}{*}{ Period of time } & \multirow{3}{*}{$\begin{array}{l}\text { Number } \\
\text { of herds }\end{array}$} & \multicolumn{4}{|c|}{ Milk } \\
\hline & & & \multicolumn{2}{|c|}{$\mu \mathrm{g} \mathrm{I} \cdot \mathrm{l}^{-1}$} & \multicolumn{2}{|c|}{$\%$ of herds with values } \\
\hline & & & $\mathrm{x}$ & SD & $<20 \mu \mathrm{g} \mathrm{I} \cdot 1^{-1}$ & $>100 \mu \mathrm{g} \mathrm{I}^{-1}$ \\
\hline South-west & $1982-1984$ & 24 & 53.9 & 22.3 & 29.2 & 20.8 \\
\hline \multirow[t]{3}{*}{ Bohemia } & $1988-1996$ & 21 & 38.7 & 49.8 & 71.4 & 9.8 \\
\hline & 1988-1996 & 29 & 31.4 & 16.4 & 51.7 & 6.9 \\
\hline & 1997-1999 & 15 & 128.7 & 53.5 & 26.7 & 66.7 \\
\hline Znojmo & 1993-1994 & 3 & 63.5 & 17.0 & 66.7 & 33.3 \\
\hline Vsetín & 1992-1994 & 10 & 28.4 & 10.9 & 20.0 & 30.0 \\
\hline Czech Republic & 2003-2004 & 226 & 310.4 & 347.0 & 4.0 & 77.5 \\
\hline
\end{tabular}

Distribution of milk iodine findings reflecting dairy cow saturation with iodine in the year 2003 is shown in Table 3 and Fig 1. Milk iodine values below $20 \mu \mathrm{g} \mathrm{I} \cdot 1^{-1}$, which are far from being sufficient as food for the men and give evidence of a deep iodine deficiency in feed rations, were detected in $4.0 \%$ farms. The deficiency is caused by iodine absence in essential feeds, not corrected by iodine supplementation. General variation of the lowest concentrations is diffuse, minute contents were detected in samples from the districts of Ústí n. Labem $\left(6.6 \mu \mathrm{g} \mathrm{I} \cdot 1^{-1}\right)$, Náchod $\left(6.7 \mu \mathrm{g} \mathrm{I} \cdot \cdot^{-1}\right)$, Most $\left(16.6 \mu \mathrm{g} \mathrm{I} \cdot 1^{-1}\right)$, Litoměřice $\left(16.5 \mu \mathrm{g} \mathrm{I} \cdot \mathrm{l}^{-1}\right)$ and Jindřichův Hradec $\left(19.9 \mu \mathrm{g} \mathrm{I} \cdot \mathrm{1}^{-1}\right)$.

Table 3. Iodine concentration in milk from dairy cows $\left(\mu \mathrm{g} \mathrm{I} \cdot \mathrm{l}^{-1}\right)$ - representation of herds

\begin{tabular}{|l|c|c|c|c|c|c|}
\hline $\begin{array}{l}\text { Iodine } \\
\text { concentration } \\
\text { in milk }\left(\mu \mathrm{g} \mathrm{I} \cdot \cdot^{-1}\right)\end{array}$ & $<20$ & $20-80$ & $80-250$ & $250-500$ & $500-1000$ & $>1000$ \\
\hline $\begin{array}{l}\text { Number } \\
\text { of herds }\end{array}$ & 9 & 33 & 85 & 61 & 27 & 11 \\
\hline$\%$ of herds & 4.0 & 14.6 & 37.6 & 27.0 & 11.9 & 4.9 \\
\hline
\end{tabular}


The iodine values between 20 and $80 \mu \mathrm{g} \mathrm{I} \cdot \mathrm{l}^{-1}$ which is the lower limit of the optimum range were found in $14.6 \%$ of cases, milk samples containing 80 to $250 \mu \mathrm{g} \mathrm{I} \cdot \mathrm{l}^{-1}$ reflecting optimum iodine saturation of cows and favourably influencing iodine contents of consumer milk and milk products in the present study were detected in 11.8 and $31.6 \%$ samples.

In the present study, we detected milk iodine contents between 250 and $500 \mu \mathrm{g} \mathrm{I} \cdot \mathrm{l}^{-1}$ in $27 \%$ farms examined. Almost one fifth of farms $(16.8 \%)$ produced milk with iodine concentrations above $500 \mu \mathrm{g} \mathrm{I} \cdot \mathrm{l}^{-1}$; concentrations above $1000 \mu \mathrm{g} \mathrm{I} \cdot \mathrm{l}^{-1}$ were found in $4.7 \%$ samples. Those values are far from the European standard and exceed the value of $0.1 \mathrm{mg}$ $\mathrm{I} \cdot 1^{-1}$, which is the current legislatively set limit for milk iodine content in the Czech Republic.

\section{Discussion}

The presented study shows the results of field monitoring the current cow milk iodine content and specifies the current knowledge on the topic. The extent, arrangement and results are comparable with the data by Preiss et al. (1997) who accomplished a similar investigation in Bavarian dairies in the year 1996. Based on their experience, Ka ufmann et al. (1997) recommended introducing complex whole Germany programmes of systematic and regular check of iodine contents of purchased milk.

Despite the sampling places were randomly selected, numbers of examinations were relatively limited by the extent of financial subventions and capacity of the laboratory, we can consider our results as representative. Their validity and merits may be based on information given by the authors studying iodine status of dairy cows by the same methodology in relationship to food milk (Anke et al. 1994a; Lee et al. 1994; Ka ufmann et al. 1997).

Multifactorial character of the causes and background of the development registered is among others iodine availability in the environment of the Czech Republic, iodine sources, optimum requirement, inevitable intake etc.; the analysis has been focused on the aspects of hygiene, technology and pathophysiology.

Wide range of individual values between $<10$ to $>1000 \mu \mathrm{g} \mathrm{I} \cdot \mathrm{l}^{-1}$ and marked differences in average milk iodine levels during past twenty years resulted from different iodine intake by dairy cows; in the former, it reflects in the between-farm differences, and in the latter, it forms an oscillating curve of average values during the investigated periods in whole groups of dairy cows (Šucman et al. 1984; Kroupová and Brožová 1986; Kroupová et al. 2001; Herzig et al. 1996).

It is well known that fodder and concentrated feeds produced in the Czech Republic contain very low levels of iodine which is given by the geographic localization (Oliverius ová 1997; Herzig et al. 1996), it has been concluded that total iodine content in the diets is primarily affected by the quality of mineral supplements. Scientific information, qualified impulses, wide offer of mineral feed supplements containing iodine and the interest of the farmers resulted in the process of general iodine supplementation in the mid-1990s. In the year 2000, distribution chain offered 244 mineral supplements containing iodine from 11 manufacturers; $94 \%$ of these products contained 5 to $700 \mathrm{mg}$ iodine $\mathrm{kg}^{-1}$. However, on the other hand, they documented a typical, experimentally demonstrated and easily controllable iodine intake by the animals and milk iodine content by the additives (Anke et al. 1989; Pennington 1990; Convey et al. 1977; Herzig et al. 1999). The use of iodine additives reflects both in optimization of thyroid gland function and iodine deposition in the internal organs, musculature and its excretion through milk.

Oscillations of average milk iodine content curve during the past period and its peak detected in the year 2003-4 in the Czech Republic (Table 2; Fig. 1) are comparable with the development and experience from the countries where general elimination of iodine deficiency was solved in the same way, i. e. by enrichment of feed rations for farm animals 
with iodine supplementation. Iodine supplementation of milk in the region of former East Germany is characterized by the increase from initial $17 \mu \mathrm{g} \mathrm{I} \cdot \mathrm{l}^{-1}$, accompanying deficiency status in the year 1985 to $53 \mu \mathrm{g} \mathrm{I} \cdot \mathrm{l}^{-1}$ in the year 1987, and $81 \mu \mathrm{g} \mathrm{I} \cdot \mathrm{l}^{-1}$ in the year 1989 (Anke et al. 1994b); five years later, i. e. in the year 1994, the level reached $130 \mu \mathrm{g} \mathrm{I} \cdot \mathrm{l}^{-1}$ (Anke et al. 1997; Anke 2004). Nevertheless, even under those conditions, cases with the values below $20 \mu \mathrm{g} \mathrm{I} \cdot 1^{-1}$ in $4.0 \%$ were detected in the year 2003-4, which according to Groppel et al. (1993) declare a marked deficiency in iodine content. However, in recent years, goitre occurrence was registered in calves from the Czech herds even if their mother milk iodine content was higher (Kursa et al. 1997; Kroupová et al. 2001). Detected minimum concentrations reflected very low iodine contents in forage, which is far from meeting basic iodine requirements of dairy cows from the tested herds. They also demonstrated that iodine deficient forage derived from the above mentioned constant conditions is unsolvable without compulsory iodine supplementation. Some farmers still underestimate the significance and implications of these measures. Primarily, attention is not given to other, less recognised consequences of iodine deficiency such as reproductive disturbances, with reduced subsequent efficiency without diagnosed causes (Luley 2000).

General character of the minimum milk iodine concentration occurrence only partly demarcates traditional regions with iodine deficiency in the environment (Oliveriusová 1997). That diffuse variation of extremely low values also revises the previous statement that low iodine content in feeds with consequent iodine deficiency in animals is connected with the regions previously specified by Čada (1988), Kurs a et al. $(1992,1997)$ and others.

Anke et al. (1994a), Kaufmann et al. (1997) and others consider iodine excretion through milk in the range of 80 to 200 or $250 \mu \mathrm{g} \mathrm{I} \cdot \mathrm{l}^{-1}$ to be the evidence of optimum saturation of cows with iodine even in a status of higher requirements and concurrently, its content in milk and milk products may be controlled. Lee et al. (1994) reported that iodine supplementation of the feed rations for dairy cows in Great Britain and resulting milk iodine concentrations increased up to $150 \mu \mathrm{g} \mathrm{I} \cdot \mathrm{l}^{-1}$, caused a 3 -fold increase in iodine intake by the man. The required daily iodine intake by in humans may be covered only by milk (150 to $300 \mu \mathrm{g}$ ), provided its content is above $200 \mu \mathrm{g}$ per liter (Stránský and Ryšavá 1997).

Concentrations between 250 and $500 \mu \mathrm{g} \mathrm{I} \cdot \mathrm{l}^{-1}$ recorded in $27 \%$ samples approach $500 \mu \mathrm{g} \mathrm{I} \cdot \mathrm{l}^{-1}$ which is considered as the upper limit by the producers in the USA dairy industry (Berg et al. 1988). That value is also the currently accepted limit in Australia. In the present study, that group of samples is one of the factors which affect a relatively steep elevation of the curve of average values with the peak reached in the year 2003; findings from another fifth of herds with the values exceeding 500 or even $1000 \mu \mathrm{g} \mathrm{I} \cdot \mathrm{l}^{-1}$ also play a significant role.

High milk iodine concentrations suggest that iodine intake by dairy cows exceeds the set requirement which is according to the norm $0.6-0.8 \mathrm{mg}$ iodine per $1 \mathrm{~kg}$ dry matter of the feed (Sommer et al. 1994). The situation may be caused by various factors, including insufficient consistency in balancing the requirement on iodine in dairy cows and mistakes of technical origin and a poor organization of handling mineral supplements. Similarly as in the human population, the possibility of accumulation of feed supplements from more than one source cannot be excluded. Undesired accumulation may occur in high producing dairy cows when mineral and vitamin supplements containing high proportions of iodine are given to them besides high-quality production mixtures containing iodine. Application of preparations containing iodine for the teat skin disinfection may also be a source of the iodine values exceeding the limit (Hemken 1980; Herzig et al. 1999).

Extreme milk iodine values exceeding $1000 \mu \mathrm{g} \mathrm{I}^{-1} l^{-1}$ in our study cannot be only considered as luxury iodine intake by dairy cows but also as a parameter of high iodine level in food milk. We assume that occasional high iodine levels in purchased milk do not pose a threat to human health for the present. Most of the risk is particularly eliminated by 
dilution during common purchase of milk and during subsequent processing. The same opinion concerning this problem in Bavaria is shared by Preis set al. (1997) and Luley (2000). Based on the results obtained, we do not regard as probable that a consumer might intake more iodine than $1000 \mu \mathrm{g}$ set by WHO as the upper limit for the man (WHO 1994), considering not only the average consumption in the Czech Republic, but also an occasional consumption of an extreme amount of milk as the only food processed in a dairy. It may be different in self- supplier dairy farms. A regular long-time daily intake of 1 litre milk or even more is quite usual in rural families. Considering the detected concentrations exceeding the upper limit, it may be questionable if such situations are quite safe. Although it seems that the upper limit of iodine concentration tolerance in humans is individual, Bürgi et al. (1982) drew conclusions based on the studies in Switzerland that the daily intake of 0.1 to $0.3 \mathrm{mg}$ is acceptable, $0.5 \mathrm{do} 1.0 \mathrm{mg}$ may cause hypertyreosis in older people and thyroid gland damage may occur in a part of population if the concentration is 1.0 to $10.0 \mathrm{mg}$. However, in any case, it is necessary so that the foragers primarily accept the presented findings. It is particularly topical to control supplementation of feed rations with the additives containing iodine according to the physiological requirements and production conditions. It seems to be suitable to keep at systematic general monitoring of iodine content in fresh cow milk with the possibility of feedback to the agribusiness (Kursa and Herzig 2003).

\section{Mléko jako potravinový zdroj jodu v České republice}

Studie přináší aktuální poznatky o zajištění potřeby jodu u dojnic posouzením jeho hladiny v mléce a o vztahu těchto koncentrací k př́ijmu jodu lidskou populací.

Metodou Sandell-Kolthoffa jsme stanovili koncentraci jodu v nativním kravském mléce, které přicházelo do mlékáren ze 226 farem v 66 okresech ČR.

V souboru 226 bazénových vzorků mléka z různých míst ČR jsme prokázali průměrnou koncentraci jodu 310,4 $\pm 347,0 \mu \mathrm{g} \mathrm{I} \cdot \mathrm{l}^{-1}$ a její významné kolísání u mléka z jednotlivých farem, vyjádřené variačním rozpětím $<10$ až $>1000 \mu \mathrm{g} \mathrm{I} \cdot 1^{-1}$. Zjištěné výkyvy jsou odezvou hlubokých rozdílů v saturaci dojnic jodem. Průměrná koncentrace jodu v mléce převyšuje nálezy zaznamenané před suplementací, která byla zahájena v létech 1997 - 1999 dvaapůlkrát a je vyšší než je současný evropský standard.

Pro hluboký deficit jodu ve statkových krmivech, který není korigován doplňkovým příjmem jodu, svědčí $4.0 \%$ vzorků mléka s hodnotami $<20 \mu \mathrm{g} \mathrm{I} \cdot \mathrm{l}^{-1}$. Koncentrace jodu v mléce nad $500 \mu \mathrm{g} \mathrm{I} \cdot 1^{-1}$ produkovalo $16.8 \%$ farem. Při bilancích jodu v krmných dávkách pro dojnice je aktuální regulovat nabídku doplňků s obsahem jodu podle fyziologické potřeby zvírat, výrobních a environmentálních podmínek. Pro tento postup je účelná celoplošná kontrola obsahu jodu v nativním mléce a pohotové předávání výsledků chovatelům.

Významně vyšší průměrný obsah jodu v mléce vykupovaném ze zemědělských závodů do mlékáren je důležité akceptovat v bilancích příjmu jodu v potravním koši spotřebitelů.

\section{Acknowledgements}

This work was performed and supported within the study of the Veterinary Scientific Committe for Food Safety of the Ministry of Agriculture of the Czech Republic and by Grant No. 1B44013/2004 of National Agency for Agricultural Research.

\section{References}

ANKE, MK 2004: Iodine. In: Elements and their Compounds in the Environment. 2nd Edition. Edited by Merian E, Anke M, Ihnat M, Stoppler M WILEY-VCH Verlag GmbH \& Co. KGaA, Weinheim: 1457-1495. ISBN: 3-527-30459-2

ANKE, M, GLEI, M, ANGELOW, L, GROPPEL, B, ILLING, H 1994b: Kupfer, Jod und Nickel in Futter- und Lebensmitteln. Ubers Tierernahrg 22: 321-362 
ANKE, M, GROPPEL, B, SCHOLZ, M, HENNIG, U 1994a: Die Bedeutung des Jodgehaltes der Milch, Molkereierzeugnisse und des Fleisches für die Jodversorgung des Menschen in der Deutschland. Rekasan-J I: $19-20$

ANKE, M, ROTHER, C, ARNHOLD, W et al. 1997: Die Iodversorgung Erwachsener Deutschlands in Abhängigkeit von Geschlecht, Zeit, Jahreszeit, Lebensraum, Stillperiode, Alter, Körpermasse und Form des Iodzusatzes. In: Köhrle, J. (Hrsg): Mineralstoffe und Spurenelemente-Molekularbiologie-Interaktion mit dem Hormonsystem-Analytik. Verlag Wissenschaftliche Verlagsgesellschaft mbH, Stuttgart, p. 32-46

ANKE, M, WENK, G, HEINRICH, H, GROPPEL, B, BAUCH, K 1989: Die Wirkung jodierter Mineralstoffmischungen für Rind und Schwein auf die Jodversorgung und Struma prophylaxe. Z Ges Inn Med 44: $41-44$

AZUOLAS, JK, CAPLE, IW 1984: The iodine status of grazing sheep as monitored by concentrations of iodine in milk. Aust Vet J 61: 223-227

BEDNÁŘ, J, RÖHLING, S, VOHNOUT, S 1964: Příspěvek ke stanovení proteinového jodu v krevním séru. Československá farmacie 13: 203-209

BERG, JN, PADGITT, D, MCCARTHY, B 1988: Iodine Concentration in Milk of Dairy Cattle Fed Various Amounts of Iodine as Ethylenediamine Dihydroiodide. J Dairy Sci 71: 3283-3291

BOBEK, S 1998: Profilaktyka jodowa u zwierzat. Med Weter 54: 80-86

BORKOVCOVÁ, I, ŘEHƯRKOVÁ, I 2001: Studium expozičních zdrojů jódu v potravinách. Zpravodaj ředitelství SZÚ Praha 6: 5-8

BÜRGI, H, BAUMGARTNER, H, STEIGER, G 1982: Gibt es eine obere Verträchkeitsgrenze der alimentären Jodzufuhr Schweiz Med Wochenschr 112: 2-7

CONVEY, EM, CHAPIN, LT, KESNER, JS, HILLMAN, D, CURTIS, AR 1977: Serum thyrotropin and thyroxine after thyrotropin releasing hormone in dairy cows fed varying amoumts of iodine. J Dairy Sci 60: 975-980

ČADA, F 1988: Patomorfologické sledování štítné žlázy telat v raném postnatálním období v nasávací oblasti SVÚ Plzeň. Vet Med 33: 69-80

FRANKE, AA, BRUHN, JC, OSLAND, RB 1983: Factors affecting iodine concentration of milk of individual cows. J Dairy Sci 66: 997

GROPPEL, B 1993: Jodmangel beim Tier. In: Anke, M, Gürtler, H 1993: Mineralstoffe und spurenelemente in der Ernährung. Gersdorf; Verlag Media Touristik, 127-156

HEMKEN, RW 1980: Milk and meat iodine content: relation to human health. J Amer Vet Med Assoc 176: 1119-1121

HERZIG, I, PÍSAŘÍKOVÁ, B, KURSA, J, ŘÍHA, J 1999: Defined iodine intake and changes of its concentration in urine and milk of dairy cows. Vet Med - Czech 44: 35-40

HERZIG, I, ŘÍHA, J, PÍSAŘÍKOVÁ, B 1996: Urinary iodine level as an intake indicator in dairy cows. Vet Med - Czech 41: 97-101

KAUFMANN, S 1997: Ergänzende Strategien zur Bekämpfung von Jodmangel in Deutschland und Südostasien: Jodanreicherung in Lebensmitteln tierischen Ursprungs. Disertation. Institut für Ernährungswissenschaft der Technischen Universität München, 95 p.

KAUFMANN, S, KURSA, J, KROUPOVÁ, V, RAMBECK, W 1998a: Iodine in milk by supplementing feed: an additional strategy to erase iodine deficiency. Vet Med - Czech 43: 173-179

KAUFMANN, S, WOLFRAM, G, DELANGE, F, RAMBECK, WA 1998b: Iodine supplementation of laying hen feed: A supplementary measure to eliminate iodine deficiency in humans? Z Ernährungswiss 37: 288-293

KROUPOVÂ, V, BROŽOVÁ, V 1986: Jod v mléce dojnic v jihozápadních Čechách. (Iodine in milk of dairy cows in South-western Bohemia). Vysoká škola zemědělská Praha, Agronomická fakulta České Budějovice. Sborník - zootechnická řada 1: 57-66

KROUPOVÁ, V, HERZIG, I, KURSA, J, TRÁVNÍČEK, J, THÉR, R 2001: Saturace krav jodem v České republice. Veterinářství 51: 155-158

KURSA, J, HERZIG, I 2003: Problematika nadbytku jodu. Studie. Vědecký výbor veterinární MZe ČR. VÚVeL Brno, $18 \mathrm{p}$.

KURSA, J, HERZIG, I, KROUPOVÁ, V, KRATOCHVÍL, P, TRÁVNÍČEK, J 1997: Consequences of iodine deficiency in cattle in some regions of the Czech Republic. Scientia Agriculturae Bohemica 28: 115-127

KURSA, J, KROUPOVÁ, V, KRATOCHVÍL, P 1992: Nutritional factors in iodine deficiency diseases in cattle. Eighth international conference on production diseases in farm animals. 1992, August 25.-27. University of Berne, Switzerland, Proceedings, p. 23

LEE, SM, LEWIS, J, BUSS, DH 1994: Iodine in British foods and diets. Brit J Nutr 72: 435-446

LULEY, S 2000: Die Iodausscheidung im Urin als Parameter für die Iodversorgung von Milchkühen. InauguralDissertation. Tierärzlichen Fakultät der Ludwig-Maximilians-Universität, München, 91p.

MAAS, J, BERG, JN, PETERSEN, RG 1989: Serum distribution of iodine after oral administration of ethylenediamine dihydroiodide in cattle. Am J Vet Res 50: 1758-1759

MATOUŠKOVÁ, O, CHALUPA, J, CIGLER, M, HRUŠKA, K 1992: STAT Plus - Manual (in Czech). 1st ed. Veterinary Research Institute Brno, 168 p.

OLIVERIUSOVÁ, L 1997: Obsah jodu v prostředí v ČR. In: Jak řešit nedostatek jodu v naší výživě. Sborník. Státní zdravotní ústav Praha, 8 p. 
PENNINGTON, JAT 1990: Iodine concentrations in US milk: variation due to time, season, and region. J Dairy Sci 73: $3421-3427$

PREISS, U, ALFARO-SANTOS, C, SPITZER, A, WALLNÖFER, PR 1997: Iodine content of Bavarian consumer milk. Z Ernährungswiss 36: 220-224

SOMMER, A, ČEREŠŇÁKOVÁ, Z, FRYDRYCH, Z et al. 1994: Potřeba živin a tabulky výživné hodnoty krmiv pro přežvýkavce. VTEI VÚVZ Pohořelice, 198 p.

STRÁNSKÝ, M, RYŠAVÁ, L 1997: Choroby z nadbytku jódu? Výživa a potraviny 52: 119

ŠUCMAN, E, CVAK, Z, KALOUS, F, SYNEK, O 1984: Some questions concerning the iodine content in milk. Acta Vet Brno 53: 65-69

TRÁVNÍČEK, J, KURSA, J 2001: Iodine concentration in milk of sheep and goats from farms in South Bohemia. Acta Vet Brno 70: 35-42

WHO 1994: Iodine and health: Eliminating Iodine Deficiency Disorders safely through salt iodization. In: Braverman, LE: Iodized salt is safe. IDD Newsletter 10: 42-43 